\title{
The Last Musketeer of the French Revolution: Exploring the Republican Political Agenda of Pierre Bourdieu ${ }^{\dagger}$
}

\author{
Gad Yair
}

Department of Sociology \& Anthropology, The Hebrew University of Jerusalem, Mount Scopus, Jerusalem 91905, Israel

\begin{abstract}
This paper argues that Pierre Bourdieu was motivated by the frustration of the French Revolution. His work continually criticized the gap between the ideological promise of the Enlightenment and the actual persistence of inequality in modern France. This paper exposes the centrality of the failed revolution in Bourdieu's oeuvre by visiting four topics he delved into: Education, gender, globalization and the role of social science. The analysis shows that the contrast between the ideals of equality and meritocracy and their poor implementation in schools and universities has motivated his sharp critique of the French system of education. Similarly, the failure of the State to support gender equality drove him to expose the deeply embodied cultural mechanisms that guarantee the advantages men have over women. The paper further shows that Bourdieu also extended this preoccupation with the failure of the Revolution to global politics. Specifically, his recent critique of globalization and global organizations suggests that capitalist Western elites betray the cosmopolitan vision of the Revolution while using international law and global companies to exploit third world countries. Finally, the paper shows that Bourdieu's preoccupation with the Revolution reappeared in the role he projected for social science and concludes that, for Bourdieu, the French Revolution is still to come. In that sense, Bourdieu was consistently preoccupied with the Revolution, and it is thus most fitting to see him, emphatically, as the last Musketeer to fight the betrayal of the French republic.
\end{abstract}

The representatives of the French people, organized as a National Assembly, believing that the ignorance, neglect, or contempt of the rights of man are the sole cause of public calamities and of the corruption of governments, have determined to set forth in a solemn declaration the natural, unalienable, and sacred rights of man, in order that this declaration, being constantly before all the members of the Social body, shall remind them continually of their rights and duties; in order that the acts of the legislative power, as well as those of the executive power, may be compared at any moment with the objects and purposes of all political institutions and may thus be more respected, and, lastly, in order that the grievances of the citizens, based hereafter upon simple and incontestable principles, shall tend to the maintenance of the constitution and redound to the happiness of all.

(The Declaration of the Rights of Man and the Citizen, August 26, 1789).

This paper argues that Pierre Bourdieu assigned himself as the representative of the French people and acted as its National Assembly. In that capacity, he set himself to work by the charter of the preamble to The Declaration: to remind the members of the social body of their rights and

*Address correspondence to this author at the Department of Sociology \& Anthropology, The Hebrew University of Jerusalem, Mount Scopus, Jerusalem 91905, Israel; Tel: +972-25883333; Fax: +972-25324339; Email: msyairg@mscc.huji.ac.il

${ }^{\dagger}$ An early version of this paper was presented at an ESA Sociology of Culture meeting in Ghent, Belgium, November 2006. I thank Eva Illouz, Zohar Gazit and Julia Resnik for their helpful comments on a previous draft. The comments made by three reviewers of The Open Sociology Journal were instrumental in further improving the paper. As always, Tracy Karp skillfully edited this paper. duties; to monitor the legislative and executive powers and compare them with the Republican purposes of ideal political and social agendas decreed by the revolutionaries of 1789; and overall, to maintain the tenets of the French constitution. In that sense, like d'Artagnan in Dumas' The Three Musketeers who also came from an impoverished family from Gascony Bourdieu took it upon himself to be the keeper of the Republican tradition of the French revolution. In a sense, then, he was the last musketeer to fight for true France.

Bourdieu's entire oeuvre was indeed motivated by the failed promise of the French Revolution and by the demise of its most noble ideals. His passionate analyses - of educational stratification, cultural production and consumption, gender relations, the social structure of the economy, and the effects of globalization - were always carried out with the moral benchmark of the revolution in mind. Bourdieu was indeed passionately tied to the values of the French Revolution, notably to liberty and meritocracy, to social equality and to the democratization and universalization of government. But wherever he looked, he saw those values betrayed by the very people who argued for their implementation and by the governmental bodies, which were devised in order to guarantee their effectiveness. Committed to the values of The Declaration of the Rights of Man and the Citizen, he was constantly frustrated by the betrayals of universalization by the Fifth Republic (1958 to the present).

The systematic analyses presented below show that Bourdieu's empirical analyses repeatedly exposed that while the French republic called for the abolition of the monarchy and the order of the estates, the members of the nobility succeeded in reproducing their class advantages while guaranteeing their particularistic interests across the generations. His studies of museums, universities, and schools exposed that the descendents of the nobility succeeded in 
guarding their position through the seemingly universalistic and meritocratic criteria of these modern institutions. Basing his arguments on detailed empirical observations, he exposed the intricate mechanisms by which the aristocrats of the ancien régime strategically maneuvered themselves in changing contexts, with their offspring continually enjoying undue privileges. Specifically, he has shown that philosophers and top state administrators, like Parisian bourgeoisie and Normaliene, are un-meritocratically over-benefitted relative to those who actually remained members of the third estate: Immigrants, the unemployed, working-class laborers, women, the petite bourgeoisie, or in other words those who were to be aspired by the ideals of the Revolution yet are repeatedly betrayed by its leaders.

I argue that the frustrating gap between the ideals of the French republic and their implementation in practice serves as a moral compass that directed Bourdieu's oeuvre. It is the core code through which Bourdieu viewed the world: Whatever he looked at, he always saw a failed moral revolution, a betrayed promise for egalitarianism and universalism. By constantly looking at social class inequalities he was able to expose how state-supported bodies - universities and banks, museums and local authorities - are used to deflecting the very ideals which justify their existence. By closely observing the microlevel action of agents - home buyers and students, music lovers and shoppers - he was able to show the complicity of the excluded who play the role of prison guards of their own imprisonment.

For Bourdieu, the ancien régime never really gave way to the Revolution. His work metaphorically suggests, then, that the Bastille still exists. But today, the régime and its powerhouses have been naturalized and neutralized. Consequently, the symbolic violence of contemporary governments is more dangerous than the physical horrors that transpired in the dungeons of the historical Bastille, for its victims - students, immigrants, the petite bourgeoisie, women, and workers - are all ignorant of their existential imprisonment by powerful symbolic counter-revolutionary mechanisms and institutions. As a result, argued Bourdieu, physical force cannot destroy this modern Bastille and its hidden regime of naturalized power. One needs a new type of weapon to battle the opaque enemies of a truly universal and egalitarian modernity: A theoretical toolkit for exposing the gaps between the ideals of the Revolution and its failed implementation.

For Bourdieu, then, the French Revolution is still in its throws, still in the making. Bourdieu's analyses suggest that he thought that the historical Revolution of 1789 failed. Nevertheless, he remained committed to its unwavering promise. He argued that in order to push for its implementation, social scientists must now fight on behalf of the public as engaged scholars. They must work, Bourdieu argued, for universalism, equality, and emancipation. It is no surprise that the role that Bourdieu ascribed for the social sciences - especially sociology was a revolutionary one [1]. After all, the Revolution and its ideals were the underlying values of this science in the first place [2].
Some scholars argue that Bourdieu's Republican stance is unexceptional, because all French critical analysts tend to appeal to "republican virtues." In that sense, this exegesis of Bourdieu's political agenda should be read as an exemplar an extremely clear one, indeed - rather than as an exceptional political analyst. Indeed, it may be just to argue that France was for Bourdieu as it was for Michelet a century before: "The "true" France was the France of the Revolution of 1789, the France that carried on the generous ideals of a nation identified with Joan of Arc" [3, p. 179]. Bourdieu, in that sense, fought to keep the enlightenment alive.

This paper sets out to expose the persistence of this deep code in Bourdieu's thought. It will thus shed new light on his immense body of writing, showing not only the persistence and utility of his toolkit - a topic well covered by prior authors who have expanded on specific concepts or ideas in Bourdieu's writings [e.g. 1, 4-7] - but rather the unvarying blueprint he implicitly used in his diverse engagements. The present paper joins previous efforts that call us "to situate Pierre Bourdieu's theory in relation to the specific French social formation which produced it" [8, p. 1017]. But rather than arguing that his positions were formulated vis-à-vis immediate historical events (e.g. the war in Algiers) or outstanding intellectuals (e.g. Sartre), the present reading offers a complementary and historically deeper argument. Fundamentally, then, this paper provides a fresh cultural or political reading of Bourdieu's oeuvre. It takes a broader view than previous efforts at interpretation, suggesting (a) that there is a persistent deep code which motivates his writings; (b) that this code fundamentally echoes the French Republican preoccupation with the morals of the French Revolution.

This analysis opens with a short exegesis of the ancien régime and the French Revolution. This shorthand historical sketch serves as background for the three examples the paper reviews, in order to show how the preoccupation with the revolution reappears in his work: In the study of education, in observing gender relations, and in criticizing globalization. The paper then reveals how Bourdieu's vision for the social sciences - epitomized in his paper "viva la crise" [9], or better yet "viva la revolution" - reflects the central role that the revolution and its failed ideals play in Bourdieu's consistent theoretical and empirical oeuvre.

\section{THE HISTORICAL BACKGROUND OF THE ANCIEN RÉGIME}

This section provides a succinct description of the ancien régime and the French Revolution. The historical literature on these themes was recently invigorated by various scholars (e.g. Furet, Hunt, Doyle), and the interested reader can consult more authoritative sources in this area $[3,10,11]$. The aim of the current review is rather simple: To provide the details required to understand Bourdieu's latent or explicit reference to the ancien régime and the frustration of the Revolution.

The ancien régime - the feudal and aristocratic order prior to 1789 - was based on a hierarchical and coercive political system $[10,12,13]$. The monarchy and the first and second estates - comprised of the Church and the nobility (400,000 people together) - ruled over the members of the third estate, the 25 million members of the third estate: the peasants $(80 \%$ of the population), the newly-rising bourgeoisie (5\%), and 
lower-class city dwellers (10\%) - who lacked political rights [3]. Louis XVI's court was a closely-knit network, and membership in the nobility was based on hereditary family lines. The title of the nobility was inherited from father to son through strict primogeniture inheritance rules. The nobles were forbidden from working and were exempt from taxation, and generally enjoyed institutionalized privileges, which at that time legally meant "distinctions, whether useful or honorific, which are enjoyed by certain numbers of society and denied to others" [quoted in $12 \mathrm{p}$. 46]. Important offices - those of judges, lawyers, and political advisers - were bought by the nobility for significant amounts of money, irrespective of talent or prior attainments. In some cases, rich aspiring members of the third estate could also buy offices and the title of the nobility, thus giving the crown a higher income and more control. However, these self-elected officers had unbound authority over the laity - and they used it arbitrarily and for their private and particularistic interests. The principle of "no taxation without participation" was yet unconceived.

This political system was backed by a corresponding feudal economic division of labor. A small minority of aristocratic land owners subjugated the landless peasants, who had to pay them with capriciously-determined taxes for use of the land, or were forced to pay for the use of mills and infrastructures. And although the subordinated farmers depended on the fields for their livelihood - and for paying taxes - the landowners often stormed the fields in their leisurely pursuit of game. In times of conflict, the laborers were forcefully drafted to their prince's battalion, but in days of drought he left them starving. By the end of the $18^{\text {th }}$ century, France experienced growing national debt, which resulted in the imposition of new ad-hoc taxation. Catastrophic weather had shrunk agricultural produce, leading to hunger, illness and death [10]. The undeserved income of the nobility and their arbitrary rule slowly accumulated to form revolutionary energies. Restlessness spread. As Beaumarchais wrote in The Marriage of Figaro (1784), "what have you [nobles] done to deserve so much? You went to the trouble of being born - nothing more" [quoted in 3, p. 5]. The ancien régime could hold no more.

Change was slow to come, however, because this unjust and arbitrary order was perceived by all parties as legitimate. It was, indeed, a doxic social order. Few doubted the monarchy, few doubted the church. Exclusionary inheritance practices were accepted as natural and the nobility of the sword was unreservedly esteemed. Suffering - mounting to unbearable levels of ill-existence was no excuse for rebellion. Consequently, accumulating frustrations needed a new platform for change. This platform was slowly developed by the philosophers of the Enlightenment - during the Siècle des Lumières - who put words to their suffering while expounding alternative political visions.

Montesquieu, Voltaire, and Rousseau supplied this intellectual platform. Their philosophical and political writings shed light on the following principles: First, social orders are man-made and obey earthly laws. Second, the current political and economic order is arbitrary and dictatorial. Third, human rights are universal and natural, constituting basic, equal entitlements for all. These philosophers raised concerns over the lack of political rights in France, and they propagated comparative cases - from democratic Greece to the new Republic of America - and stirred the rising bourgeoisie to take action towards their emancipation. Through a series of political revolts symbolically painted through the storming and destruction of the Bastille - the ancien régime seemingly dissolved in 1789. A new man-made order was outlined and its ideals were forcefully stated in one of the most important modern texts: The Declaration of the Rights of Man and the Citizen (August 26, 1789). The following excerpts of three out of the 17 statements reflect the basic ideals of the Revolution - the very ideals which set to negate the ancien régime.

1. Men are born and remain free and equal in rights. Social distinctions may be founded only upon the general good.

2. The aim of all political association is the preservation of the natural and imprescriptible rights of man. These rights are liberty, property, security, and resistance to oppression.

3. The principle of all sovereignty resides essentially in the nation. No body nor individual may exercise any authority which does not proceed directly from the nation.

Driven by the vision of liberté, égalité, and fraternité, the new French Republic was to be meritocratic and egalitarian. It was to be run by a strong state, which was to cater for equality through re-distribution of resources; it was to follow principles which were later conceptualized as "the welfare state." By making a break between its past and its future - what Bourdieu conceptualized as an historical "critical moment" vis-à-vis the quasi-revolution of 1968 [14] - France promised to turn enlightened political visions into working governance structures. Reflecting on those promises, Victor Hugo another ardent republican defender - said that the National Assembly "spread immense rays of light parallel to the eternal laws, rays that have remained on the horizon, visible forever in the heaven of the peoples, and which are, one, Justice; another, Tolerance; another, Goodness; another, Right; another, Truth; another, Love" [15, p. 197].

As will become clear through the next four sections of this paper, those Republican values and their utopian social order were the very ideals Bourdieu embraced throughout his work as well. As stated in the preamble for the Declaration, he used them to measure the deviation of modern France from its own aspired just vision. In countering the declaration of the National Assembly of 4 August 1789 - namely that the ancien régime was "totally abolished" - Bourdieu was keen to expose that it actually lingers on. The following analysis thus argues that in writing his critical sociology Bourdieu gave expression to larger historical forces and to a traditional political agenda. His spirited judgments regarding the betrayal of contemporary elites in France were essentially part of the French Republican tradition [16]. In a way, then, Bourdieu reflected the French Republican habitus. This centuries-old cultural and political tradition was already characterized by the Comte de Ségur in the 1780s, two hundred years before Bourdieu expounded his ideas:

From one end of the kingdom to the other opposition became a point of honour. It seemed a duty to 
distinguished minds, a virtue to the generous, a weapon useful to the Philosophes in their struggle for liberty: in fact a way of distinguishing oneself and a fashion which all youth adopted with ardour [quoted in 12, p. 14].

In this sense, then, it seems that in writing his critical studies Bourdieu adopted the classical medium for gaining prestige in French intellectual circles. For more than 200 years, this medium - a French habitus of which Bourdieu is perhaps the most astute exemplar - was expressed through the critique of the ancien régime or its reincarnation in the modern French republic. Bourdieu's preoccupation with the old order and with the failure of the Revolution attests to the persistence of this French intellectual tradition and to its central place in shaping the unique path of contemporary French sociology [16]. As Lemert suggested years ago, "Perhaps only in France could a discipline whose very essence is the critique of social traditions wed itself to the most revered of the traditions it critiques" [17, p. 689].

In appreciating Bourdieu's critical stance vis-à-vis central institutions in contemporary France, one should bear in mind, indeed, that these institutions are all children of the Revolution. These include the public museum, universal and free schooling, the Institute Nationale, the national polytechniques and the system of the Grandes Écoles. All of those were mandated as State institutions, which should embody the principles of equality, meritocracy, and justice.

The following three sections - focusing on education, gender and globalization - expose how the frustration with the fruits of the Revolution directed one of the most creative and ingenious minds that this cultural tradition produced. The fourth one - on the revolutionary role of sociology - shows that this preoccupation with the revolution indeed emanates from a unifying deep code, a unique French Republican intellectual habitus.

\section{THE BETRAYAL OF SCHOOLING}

The primary schools shall have as their aim the provision, for children of both sexes, of the instruction necessary for free people...the pupils shall be taught: $1^{\text {st }}$, reading and writing, and the reading selections shall make them conscious of their rights and duties; $2^{\text {nd }}$, The Declaration of the Rights of Man and the Citizen, and the constitution of the French Republic; $3^{\text {rd }}$, elementary instruction in republican morality; $4^{\text {th }}$, the elements of the French language...

(Decree relative to Primary Schools, 17 November 1794).

You're a normalien just like you're a hereditary prince. Nothing shows it on the outside. But everyone can tell, everyone can see it, even though it's polite, and even humane not to show it off (...). This quality is consubstantial. You don't become a normalien, you're born one, just as people used to be born knights [18, p. 453, quoting George Pompidou, President of France 19691974 ].

In the Decree Relative to Primary Schools, adopted by the National Convention on 17 November 1794, the revolutionaries promulgated the vision of a universal, free, secular education that was aimed for all girls and boys, and that was provided and supervised by the State. The school was to cater for a common language while invoking common republican sentiments, mainly through the participation of pupils in national ceremonies and holidays. It was also to guarantee a common language and a common collective conscience.

The school was, indeed, to be the most revolutionary of all reformed social institutions. It was the mechanism which promised - more than all others - to break the ancien régime and constitute the Republic on meritocratic grounds; it was geared to tear down the monopoly of the nobility and open up arenas for the equal cultivation of talent; and it was to be the "liberating force" which would neutralize familial advantages that usually worked for the benefit of the elites. In other words, it was a planned institution which derived its organizational structure from the principles of the Declaration: It was to be universally attended by all; it was to promote achievement and disregard ascriptive advantages; and it was to encourage merit, talent and effort over hereditary advantages. The formal school system was therefore not just a symbol for the new Republic. Rather, it was the practical mechanism that promised to correct for the ills of the ancien régime and build the new French Republic. It was to root out tradition and irrational religious beliefs, and espouse republican revolutionary values which would guarantee the functioning of the new order of virtue and reason [3].

Instead of implementing liberté, égalité and fraternité, argued Bourdieu, France systematically evaded those values. True, it declared its commitment to those values and celebrated the spirit of the revolution. However, the ideals remained a state-maintained façade, an ideology that concealed the continuity of oppression, inequality, and elitism in a new guise. This betrayal of the state is apparent in different faces and phases of the system of education.

Through a series of critical studies - notably The Inheritors [19], Reproduction in Education [20], Homo Academicus [14] and The State Nobility [18] - Bourdieu exposed the fact that the French system of education did not stand up for its aspirations. Rather than constituting a revolutionary force, it turned to be a conservative one. Compared to the revolutionary ideals, it was a failed utopia.

The first negation of the ideals concerns the charter of the modern school, namely its promise to be universally open. In contrast with this seeming aspiration, however, Bourdieu exposed that the school developed into a selective system, tapping on students' cultural capital. Schools and universities consistently preferred the wealthier students, those who learned to appreciate at home what the schools were supposed to teach to all equally - art, literature and poetry, history, citizenship, and even philosophy. Instead of a strong and mandatory institution, the school remained weak. It did not take its duty to provide equal opportunities for all seriously, and it did not guarantee that credentials were distributed individually on the basis of merit. This institutional weakness allowed elite families - inherently a conservative, counterrevolutionary force - to work their way through the system while maintaining their traditional elitist advantages. This critique of the weakness of the school - and its betrayal of universality - was clearly expressed in The Love of Art: 
The difficulty of breaking the circle which ensures that cultural capital reproduces cultural capital becomes clear: The school only has to let the objective mechanisms of cultural diffusion run their course and refrain from working systematically to provide everyone, in and through the educational message itself, with the instruments necessary for an adequate reception of the academic message, for initial inequalities to be intensified and for the transmission of cultural capital to be legitimated by its sanction [21, p. 70].

The second face of the school's failure was apparent in its ignorance of the meritocratic ideal. Bourdieu repeatedly showed that like in ancient times, teachers and professors still preferred "grace" over hard work, "elegance" over perseverance, and "style" over diligence. His scathing analyses of different phases of educational careers showed that teachers frown at hard-won achievements by the common people, seeing in effort and perseverance the signs of moral failure. In contrast, these same teachers look at the academic failures of the socially elect as excusable slips. Thus, instead of relying on objective achievements, schools and universities evince preferential selection that is biased toward culturally-congruent students; toward those whose family backgrounds promise them noble success, irrespective of their academic performance.

Third, the modern French school system failed to achieve the ideals of the Declaration because it proved to be non-egalitarian. Bourdieu pointed out that instead of exhibiting egalitarianism, the system retained a highlyhierarchical structure: Some schools and programs only led to vocational destinations, others to the baccalauréat. From there, more hierarchical groupings evolved, and hierarchies transpired even in the most selective institutions. This hierarchical aristocratic order is also apparent in the order of knowledge. The disciplines of French and philosophy, for example, are appreciated far more than geography and sociology because they heavily rely on aristocratic cultural capital. Wherever he looked, then, he saw that the ancien régime was still operating, its nobility still firmly in place.

Paradoxically, this betrayal of the revolutionary spirit passed unnoticed by most people, inciting Bourdieu's bold critique:

It was therefore necessary to bury the myth of the "school as liberating force," guarantor of the triumph of "achievement" over "ascription," of what is conquered over what is received, of works over birth, of merit and talent over heredity and nepotism, in order to perceive the educational institution in the true light of its social uses, that is, as one of the foundations of domination and of the legitimation of domination [18, p. 5].

Bourdieu felt obliged to expose not only the nonuniversal principles and the non-egalitarian structure of modern schooling, but also the subtle mechanisms, which legitimated this camouflaged counter-revolutionary system. In doing so, he again used the metaphor of the ancien régime, because this most unjust order was an exemplar of false legitimization. Using quantitative data and in-depth observations, Bourdieu exposed the silent mechanisms of domination, which work through schooling. One mechanism was the use of educational credentials. Following the Revolution, suggested Bourdieu, educational certificates became the new principle that the state used for the ordination of its noblese de robe (the nobility of the robe, referring to lawyers and judges). The "Licence," "Maitrise" and "Concours" - which he exposed to be socially distributed in accordance with students' cultural capital, rather than according to their true intellectual merits - turned out to be the new magical means used by the government for electing its "state nobility". As Bourdieu blatantly said,

...the state nobility, initially in the guise of the noblesse de robe, and the academic title, as a "patent of education" guaranteeing privileges, were born of correlative and complementary inventions. The state nobility, whose power and authority, both in their punctual efficiency and their reproduction, are founded, to a great and ever-increasing degree, on the academic title, is the product of an inseparably practical and symbolic construction operation aimed at instituting positions of bureaucratic power that will be relatively independent of the previously established temporal and spiritual forms of power (knights [la noblesse d'épée, nobleman of the sword Tr.], the clergy, etc.) and creating a hereditary body of agents entitled to occupy these positions in the name of competence sanctioned by educational institutions expressly designed to reproduce it [18, p. 377].

Another mechanism of legitimization worked through the transformation of arbitrary social differences into natural hence opaque and legitimate - differences. By emphasizing concepts like "talent" and "precocity" - features he showed to be highly supported and cultivated in elite families - the modern school system naturalized arbitrary pre-school differences. It thus - inadvertently - turned a blind eye to its counter-revolutionary stance. By using different intellectual measures (e.g. the IQ scales originally developed by Binet for helping weak students in school), the French school system ordained the new intellectual nobility. It used seeminglyobjective psychological criteria to select the social groups, which were "naturally" suited to govern France. Not surprisingly, these seemingly universal and objective measures turned out to be based on cultural capital - the latent tools of reproduction of family privileges [22].

Even more subtle mechanisms were revealed by in-depth analyses of assessments of "prizewinners of the Concours Général." These prize winners - notably students from elite, highly-educated families - were selected through culturallymediated conceptions of excellence - preferring elegance over vulgarity, ease over effort. These cultural orientations to texts, broadly defined, reflected and simultaneously neutralized and hid primordial pre-academic differences. Coming from the ancient traditions of the nobility, they helped maintain traditional privileges in a seemingly-meritocratic setting.

This analysis shows that Bourdieu saw the modern French system of education as running parallel to the ancien régime; actually, he saw it as the continuation of that system with slight transformations. He was aware that by drawing this parallelism he turned into the enfant terrible of the French academic system. Yet he insisted that the similarity and 
continuity between the systems should not be repressed or denied. To quote:

It is usually in the name of comparison, nearly always implicit, between the defects of the ancien régime and the virtues of academic meritocracy that people have viewed the implacable findings of sociology as the expression of a kind of irresponsible ultra-radicalism, which cloths in the garb of utopian egalitarianism a kind of "the worse the better" politics, liable to drive the republican primary school teacher to despair [18, p. 373].

There is no doubt, then, that Bourdieu had the ancien régime in mind when analyzing the functioning of modern schooling. Time and again he concluded that the system betrayed its values; time and again he was devastated to learn that the elites never really aspired to attain the ideals of the Revolution; and time and again he was disappointed to know that his was the only voice in the renewed and enlightened fight for Republican morality. For Bourdieu, the ancien régime is still here, and 1789 is practically still to come.

\section{THE BETRAYAL OF THE STATE AGAINST WOMEN}

One of the most renowned pictures of the French Revolution, painted by Eugene Délacroix, portrays Liberty Leading the People (1830). In this painting, the heroine holds up the French flag in one hand, a rifle in the other. With breasts exposed, she leads her compatriots to rise over the bastions of power and free the people from despotism. This painting suggests - like many others preceding it - that women had an important symbolic role to play in the Revolution and, like men, they too sought political freedom and social equality $[23,24]$. This artistic representation is supported by recent historical studies [25, 26]. Women were major players in the early days of the Revolution. Like men, women in 1789 had a political and civil agenda in marching on Versailles: A universal claim for egalitarian, universal citizenship. As Olympe de Gouges said in rewriting the Declaration, "woman is born free and lives equal to man in her rights" [quoted in 3, p. 59].

The Revolution indeed promised freedom for all. It promised to liberate the third estate, the slaves in the colonies, and the Jews and other religious minorities. In principle, it promised to liberate women too. The Declaration - though literally referring to men rather than to women or to people more generally - was therefore phrased in the most universal terms. It promised a fully humanized social order: Egalitarian, just, meritocratic and with freedom for all. As the preamble for the Declaration decreed, state institutions - schools, museums and government offices, for example - were to guarantee these rights and fight against non-egalitarian traditions. State institutions were to target orthodox and conservative institutions like the family and work for the universal benefit of all, irrespective of status at birth. The state was to cater for gender equality, just as it promised to do in other domains. During the historical moments of the Revolution, women had indeed won the right to form their own political clubs, gained the right of divorce and achieved the right for equal inheritance. But these achievements were soon short-circuited. The feminist Olympe de Gouges - who in Article X of her revised Declaration said that "No one is to be disquieted for his very basic opinions" - was executed by guillotine. Soon, all enlightened voices were silenced by terror. Consequently, the subordination of women persisted, their equality adulterated by the institutions, which promised liberation from the ancien régime. Actually, women's social standing even deteriorated under the regime erected on the Napoleonic code in 1799. Locked back within the private sphere of the household, women lost their meager rights and had to wait until 1944 to be granted what the Revolution promised before: The right to vote and the right to be elected to office. But even this late democratization was far from attaining the promise of universal rights for women, especially their embodied manifestation in egalitarian gender relations.

This betrayal of the Revolution frustrated Bourdieu. He used different sources to show that what was claimed by feminist authors before him is indeed true: Women do not occupy prestigious occupations; they are under-represented in top academic positions; they are excluded from political offices; and they are more poorly remunerated than men, even when performing the same jobs. Furthermore, he argued that women can only succeed in society if they play on their femininity - as actresses, TV hostesses, dancers or singers thus reproducing the gendered social order and the overall inferiority of women with respect to men.

There was nothing empirically new in Bourdieu's description of gender inequality in Masculine Domination [27]. Actually, other than his original observations of the Kabyle in Algiers, Bourdieu did not collect new evidence about the position of women. Available empirical evidence was ample and consistent: The gaps between men and women are persistent, as are the deeper masculine and feminine traits and behaviors, which correlate with these gaps. Furthermore, there were many feminist studies that exposed those inequalities and deciphered mechanisms that work to the advantage of men - who in the Marxian tradition, at least, were criticized for exploiting women through the reproduction of the household [28, 29].

Bourdieu was not content with these prior critiques. He wrote Masculine Domination in order to expose the mechanisms that "eternalize the arbitrary": The mechanisms that conceal the constructed and arbitrary division of labor between men and women. In doing so, he criticized the use of essentialist explanations, which State officers use to justify the universal stratification between male and female. Bourdieu criticized those who argue that "the division between the sexes appears to be 'in the order of things', as people sometimes say to refer to what is normal, natural, to the point of being inevitable" [27, p. 8]. His view of this position goes back to his critique of pre-revolutionary France and to the failure of the Revolution in actually changing the order of things. The ancien régime seemed 'in the order of things' too; but it was nevertheless an arbitrary social order. It was accepted because it was sanctified and naturalized by papal authority and monarchical rule. Consequently, the social positions of members of the third estate - though dominated and exploited - were always deemed natural and inevitable. However, as the philosophers of the enlightenment argued, this traditional 
social order was far from being natural and justified. Rather, it was arbitrary and lacked rational legitimization.

Bourdieu followed this tradition in deconstructing the seemingly "natural" division of labor between men and women. He argued that all differences are social: They are artificial, socially constructed and arbitrary. As he said, even "the visible differences between the male and female sex organs are a social construction which can be traced back to the principle of division of androcentric reason, itself grounded in the division of the social statuses assigned to men and women" [27, p. 15]. His analysis set to deconstruct this essentialist position, showing that the socially constructed and arbitrary differences between the sexes have always worked to the advantage of men. But given their social origins, they can be transformed through the hard work of reflexive deconstruction - in order to match the ideals of the Enlightenment.

The ancien régime was indeed a major premise he used in considering masculine domination. Bourdieu equated men with the nobility, women with the exploited. In his view, both are "prisoners, and insidiously victims, of the dominant representation" [27, p. 49]. Just as the nobility had to evade working life in order to retain their noble status, men have to be masculine and dominating, for otherwise they risk shame and humility. The metaphor of the old regime is indeed explicit. As Bourdieu wrote in the context of masculine domination,

Nobility, or the point of honour, in the sense of the set of dispositions regarded as noble (physical and moral courage, generosity, magnanimity, etc.), is the product of a social labour of nomination and inculcation at the end of which a social identity instituted by one of the 'invisible demarcation lines' laid down by the social world and known and recognized by all inscribes itself in a biological nature and becomes habitus, embodied social law [27, p. 50].

Men and women are social products, then. Their behavior, traits and feelings result from the arbitrary work of social construction. The division of labor between the sexes is also a social construction: an arbitrary hierarchy that is masked through recourse to essentialist, natural explanations. The consequences of the naturalization and eternalization of gender hierarchies result in opaqueness leading men and women to perceive their social differences as unproblematic. Minted into a historically formed, yet universally diffused, gendered habitus, these social differences take the revolutionary sting out of feminine subordination. Tradition and essentialist scientific explanations converge to form a doxa, a normal perception; a perception that says that gender hierarchies are embedded in the very nature of things, and hence unobjectionable. More than most sociologists, Bourdieu sought to show how these violent beliefs are internalized by their victims, serving to perpetuate gender hierarchies. As he said,

Girls internalize, in the form of schemes of perception and appreciation not readily accessible to consciousness, the principles of the dominant vision, which lead them to find the social order, such as it is, normal or even natural and in a sense to anticipate their destiny, refusing the courses or careers from which they are anyway excluded and rushing towards those for which they are in any case destined. The constancy of habitus that results from this is thus one of the most important factors in the relative constancy of the structure of the sexual division of labor [27, p. 95].

Like in the ancien régime, men and women acquiesce with their respective positions and with their arbitrarily imposed differences. Therefore, Bourdieu joined feminist critiques of the established order, of masculine domination, calling for gender equality. His opponents, though, are not men and their household behaviors. His concerns were not with the private sphere. Rather, he aimed his critique at the public forces and the administrative organs that betrayed the revolutionary ideals, which were proposed in 1789 in order to guarantee universal emancipation. In other words, he pointed his theoretical spears at the State. The French State - immediately after 1795 - failed to work toward gender equality, and it actually played an active role in the preservation of gender relations in the ancien régime $[25,26]$. The state was responsible - through its administrative organs, like the school and its regressive family code - for the perpetuation of the gendered habitus of men and women. Like in traditional societies, post-revolutionary France worked to guarantee men with advantages and power over women. To Bourdieu's amazement, it still does so. It thus keeps betraying its role as an emancipating force while deluding all parties that it is really working to guarantee universal rights for all.

This betrayal of the spirit of the Revolution necessitates another stab in the ancien régime. This intellectual critique should start, argued Bourdieu, by re-inserting "into history, and therefore to restore to historical action, the relationship between the sexes that the naturalistic and essentialist vision removes from them" [27, p. viii]. But intellectual weapons are not enough, he argued. There is the practical need for "political mobilization, which would open for women the possibility of a collective action of resistance, oriented towards legal and political reforms" [27, p. viii]. For Bourdieu, women have to reinsert themselves into the scene depicted by Délacroix - to carry a flag and a rifle and "to invent and impose forms of collective organization and action and effective weapons, especially symbolic ones, capable of shaking the political and legal institutions which play a part in perpetuating their subordination" $[27$, p. ix]. In other words, women need to rise up against male-dominated bastions of power, deconstruct them, and reform them through the revolutionary spirit of egalitarianism, universality, and justice. As Bourdieu concludes, they have to revolutionize the State in order "to contribute to the progressive withering away of masculine domination" [27, p. 117]. The masculine Bastille is to be deconstructed, if not destroyed.

Published 210 years after the French Revolution, Bourdieu's Masculine Domination (2001) clearly conversed with revolutionary images and ideals. Actually, the appreciation of Bourdieu's analysis of gender relations and their stubbornness across the ages is significantly expanded by placing it against his understanding of the Revolution and its frustration. As a matter of fact, there is a one-to-one correlation between the protagonists in his analysis - men as 
the nobility, women as the third estate; there is also a clear parallel in his understanding of the arbitrariness of this artificial class-based division between men-as-nobles and women-as-the-poor - both resulting from socially constructed and interest-laden power relations. This concordance goes even deeper: The ancient regime helps Bourdieu to account for the reproduction of gender relations, and the Revolution - with the march of women on Versailles - providing him with the courage to entertain the idea of a possible egalitarian future which would follow the political action that women engaged with 200 years before he set his mind on gender inequality and male domination. As this analysis suggests, without recourse to the revolution and the ancien régime, one can have but a partial understanding of Bourdieu's feminist writings.

\section{THE FRUSTRATIONS OF GLOBALIZATION}

The revolution was not to be a French particularity. Its values had a global thrust, its principles a universal appeal. Unlike the English Bill of Rights of 1692, The Declaration of the Rights of Men and the Citizen was phrased in universal terms. It stated that all men enjoy inalienable rights and that all men - not just French citizens - should be free from oppression and have the civil rights to resist authoritarian rule. It set universal principles for free speech and declared that freedom of thought and freedom from religious doctrine require a strong sovereign - whose sole task is to protect those civil rights. As principle XII suggests, "This [public] force is...instituted for the advantage of all and not for the particular utility of those to whom it is confided."

The nation state - the new administrative mechanism which evolved during the $18^{\text {th }}$ and the $19^{\text {th }}$ centuries promised to embody these universal principles in law and structure. It vowed to develop new principles of taxation and redistribution in order to guarantee at least a basic economic standing for all, and cater for the needs of young and old, poor, insane and sick people. By monopolizing control over all forms of capital, the modern state promised to take a universal stance [30], and develop responsibility under the principle of in loco parentis. It promised, in other words, to embody and protect the ideals of the Revolution.

The ideals of the Revolution indeed had a universal appeal. The French national anthem was repeatedly sung in Poland, China and Russia, and the example set by the French revolutionaries - proving that people can bring down dictatorial regimes - has constituted an historical lighthouse for many oppressed people. Indeed, France was the first global power to abolish slavery, and by doing so it sent a strong political signal to other colonial countries. Though far from perfect, and indeed after repeated setbacks, the French welfare state, especially after the Second World War, attempted to finally embody the Republican ideals of the Revolution: From the monopolization of schooling to nationalization of health care, from progressive taxation on to the determination of maximal working hours. The strong state - strong thanks to its capacity to monopolize its control over all sources of capital [31] - enabled it to take long strides toward the universalization and equalization of civil, human and economic rights for all. Consequently, the global vision of the French Revolution - promising egalitarianism, emancipation and social responsibility - seemed to be achieved, or at least evolving in the right direction.

If this self-presentation was ever right, argued Bourdieu, it is now patently false and mystifying. In the last years of his life, Bourdieu set out to show that the moral promises of the revolution are betrayed by new global formations and neoliberal ideologies. His critical analyses of globalization appearing in On Television [32], Acts of Resistance [33], Firing Back [34], and The Social Structures of the Economy [35] - showed that human and civil liberties are currently under growing threat. For example, freedom of speech is curtailed today by the control of television stations by private owners; freedom of thought is limited by the commercialization of book printing; freedom of research is under constant attack by university governing bodies which represent the interests of the (wealthy) public. Public radio and public television - once the vanguard of public interests - have given way to interest-directed media barons. A similar transformation took place with regard to once-independent newspapers and magazines while public services (e.g. schooling, transportation) are all imperiled.

Bourdieu's angry analyses of these processes show that they are not random. Rather, he shows that they reflect a global policy, which is pushed by American particularistic interests that dominate the entire world. Bourdieu argued that American particularistic economic theories - in the guise of universal scientific theories - help global firms to dominate the world economy without need for force. The strong state succumbs in face of these global ideologies. Instead of guarding its citizens, it de-nationalizes its powers. Speaking new neo-liberal global speech [36], it shrinks its regulating capacities and minimizes its involvement in welfare policies. These changes produce a weakened citizenry, which is now as it was in days of old - fully controlled by capitalist interests. Rather than defending the rights of men, the new government cooperates with global actors, thus defending the interests of global corporations. But in doing so, it steps back to the worst days of capitalism in the $18^{\text {th }}$ and $19^{\text {th }}$ centuries.

These changes set the wider context for Bourdieu's critique of neo-liberalism and globalization. He argues that the universal ideals of the Revolution and its moral promise for the world are now run down by a heartless, compassionless and dictatorial American government, which obeys capitalistic interests and maintains global control via international bodies - the World Bank, the World Trade Organization, and the International Monetary Fund.

The conditions, which allow this totalitarian control, are the same as those, which have functioned to build national economies: Concentration of production and control over distribution. These are, in essence, political processes, for they end up with domination and dispossession. "Unification and integration," argues Bourdieu, "are accompanied by a concentration of power, which may reach monopoly proportions, and, at the same time, by the dispossession of part of the population thus integrated. This means that integration into the state and the territory it controls is in fact a precondition for domination" [35, p. 223]. However, integration of global markets sets new forces in motion. These forces weaken the nation-state - the supposed vanguard of the revolution - and thus work against the interests of the 
dominated classes. Actually, these changes hurt the citizens of most countries in the world because the single rationale, which drives the global market is economic efficiency - decreasing costs of labor, increasing exploitation and the closing down of local markets. Hence, previously strong nation-states, who used to defend the rights of their citizens, are left incapacitated to do that anymore. Even traditionally left-wing governments find themselves pushing toward non-regulated free markets. They too encourage privatization and they too cut welfare defenses against temporary and long-term economic setbacks. In that sense, globalization is not just an international economic policy; it also leads to self-same weak national governance regulations that are driven by a neo-liberal economic theory. According to Bourdieu,

Integration into the global economic field thus tends to weaken all regional or national powers, and, by discrediting all other models of development, particularly national models, which are condemned from the outset as nationalistic, the formal cosmopolitanism in which that integration cloaks itself leaves citizens powerless in the face of the great transnational economic and financial forces [35, p. 230].

One might argue that Bourdieu's critical analysis of globalization and the decline of the welfare state is not unique. What is nonetheless unique is Bourdieu's untiring reference to the republican ideals of the French Revolution. What is also idiosyncratic is his use of the ancien régime and the Revolution as major interpretive prisms through which he appreciated contemporary historical developments. The present paper clarifies why Bourdieu was so relentless regarding the French government and its coopted nobility, the state administrators. He criticized those in political power for having given way to economic elites. However, his arrows were also aimed at the major culprits of globalization - the American government and American corporations. Because of its advantages - financial, economic, political, military, cultural, linguistic and symbolic - the United States of America has turned into a world-dominating country, or rather into an economic dictatorship. It is an ancien régime reincarnated.

As in days of old, this domination was achieved without access to physical power, and no resistance was felt from the beginning. Bourdieu argued that this particularistic dictatorial rule of the US was achieved through the consent of the dominated, because its policies were legitimized through its globally-accepted economic theory, namely neo-liberalism. Everybody seems to accept as true that people are rational actors who orient their actions in order to maximize economic gains from every transaction; few doubt that the free market is the best policy for engendering rationality and for expanding profits; few believe today that governmental involvement in economic activities will work for the greater good; and fewer still believe that state-controlled regulations of the economy and the labor market will work in favor of the workers.

Bourdieu would not be that troubled if neo-liberalism was merely a scientific theory. He was troubled because it has turned into a normative guide for action, a blueprint for the design of perfectly-run economies. However, neoliberalism is a particular theory. It results from the uniquely American version of frugal capitalism - the same system that Max Weber was morally horrified by [37] - and it is surely not a universal, or a universally agreed-upon, worldview. The spread of neo-liberalism is colonialism in a new guise, argued Bourdieu. But this consented colonialism is as wrong as any colonial rule was before it. Furthermore, its consequences are as devastating as were those of the worst colonial regimes of the past. In contrast to the vision of the Enlightenment, the new world order turns into a class-based global society: Managers of global corporations constitute the new powerful nobility, while most citizens become members of a disenfranchised third estate. As Bourdieu cynically observed, there is nothing new under the sun, because:

History carries an important lesson: we are in a game in which all the moves made today, wherever, have already been made - from the rejection of politics and the return to the religious, to the resistance to actions by a political power hostile to intellectual things, via the revolt against the grip of the media, or the disabused abandonment of revolutionary utopias [38, p. 343].

Using the concept of "field", Bourdieu was able to explain how social change is generated within a larger context of reproduction and social stasis. Globalization scholars argue that there are new actors and seemingly new moves in the social space, but for Bourdieu all that simply reflects the same structure and the same positions, which the ancien régime reflected. For Bourdieu, then, globalization is a new guise of an old particularism writ-large. It is a new dictatorial system oppressive and anti-democratic. Worst of all, globalization pushed the nation-state to shrink its administrative capacities through international legislation and regulations - thus working to bypass prior achievements of the revolutionary welfare state. This move toward de-nationalization thereby risks previously-achieved civil rights and decreases the support that the nation-state guaranteed for the weaker sectors of the population. Notwithstanding the achievements that the Revolution made in the long haul, they are now imperiled by new counter-revolutionary forces.

Bourdieu was astounded by the fact that globalization and the weakening of state support for the poor pass almost unnoticed by their victims. In his recent book, The Weight of the World [39] Bourdieu went to the streets to record the social suffering of those most hurt by globalization - e.g. North African immigrants - and to detail the confusion experienced by street-level bureaucrats who are left to attain egalitarian revolutionary ideals with incapacitated administrative organs. For the latter, implementing welfare policies has become "an impossible mission." They are caught in the double bind of contemporary de-nationalization of the welfare state. The culprit, suggested Bourdieu, is "institutional bad faith" - for there is "the constant propensity of governmental institutions, in a sort of collective double game and double consciousness, to reject or to challenge the measures or acts that really conform with the official vocation of the government" [39, p. 205]. And for Bourdieu, that "official vocation" was the revolutionary Republican one.

As a matter of fact, Bourdieu thinks that globalization and de-nationalization reawaken the ancien régime: Modern society is a system for the domination of the few over the 
many, enabled by the pathetic consent of the many to the mechanisms which dominate them. The state administration - housing the descendents of the ancient nobility finds it difficult to struggle for universal rights because they inherited the aristocratic habitus which now fits with global speak. They are at ease while cooperating with chairmen of banks, corporate managers, and media barons. Locked in their rich Parisian offices, they lose touch with the people on the streets. Bourdieu found this to be an unforgivable betrayal: While they are employed by the state - which was to cater for universality and egalitarianism - French administrators are pushing toward de-nationalization and de-regulation. While gaining their livelihood from the fruits of the revolution, they remove the minimal living conditions from those whom the revolution originally had in mind.

By studying globalization, then, Bourdieu sought to expose how this historically-contingent and arbitrary system developed. By closely investigating how people think about themselves - as workers and shoppers, homebuyers and consumers - he revealed how the dominated rejoice in their domination, suffering but endlessly believing that they are one step away from enjoying the economic riches that capitalism promises for all. Bourdieu was not a Luddite, and he did not assume globalization would wither away. True, globalization was counter-revolutionary in that it weakened the state and hurt the social rights of the majority. This is why we need a counter- counter-revolution, suggested Bourdieu. But while prior revolutions were national, this time we need a global revolution. The project of the French Revolution is now to be expanded globally. There is now a need to universalize human and social rights for all. Given the predominance of global actors, globalization needs to be challenged by global agendas that would work toward the attainment of universal aims: Social, environmental and civil.

It is doubtless not unreasonable to expect that the effects of the policy of a small oligarchy, concerned only for its own short-term economic interest, may promote the progressive emergence of political forces, themselves also global, capable of gradually imposing the creation of transnational bodies with a remit to control the dominant economic forces and subordinate them to genuinely universal ends $[35, \mathrm{p}$. 232].

Bourdieu was fully conversant with contemporary social change. He was aware of the macro-level changes, which transform modern states and he was attentive to developing governmental policies. However, Bourdieu was at bottom an ethnographer. He was keen to learn how ordinary people live: to know their joys, to appreciate their suffering. His most recent work on globalization tied his macro-level awareness with his micro-level sensitivity, thus supplying us with a detailed bottoms-up perspective about life in a globalizing French society. His rich and empirically detailed analyses of immigration, of unemployment, of home buying and endless traveling to work have thus given a sophisticated voice to those who lack insight into the ways in which history and biography, globalization and their personal lives mesh together.
But as argued previously, in enlightening the public through his critical publications Bourdieu was calling on the most diffused habitus of the French society. He used the language and metaphors of the French Revolution to tell his audience that the revolutionary project is yet to fulfill its promise. His critique of the US and global corporations aimed to show that a new old regime is arising, one that is more powerful yet symbolically more opaque and violent than the ancien régime. His bashing of the French government sought to expose that the state nobility - ministers and civil servants are the accomplices of this new global regime. In order to expose contemporary reality for what it is, Bourdieu used the ancien régime as a leitmotif. By thinking backward, he was able to think forward [40].

\section{THE REVOLUTIONARY ROLE OF THE SOCIAL SCIENCES}

Bourdieu was not content with simply demonstrating that the ancien régime is still here. He was also reluctant to settle on a descriptive social science, which tolerates the betrayal of the values of the revolution. His model of science was involved, critical and disturbing - it was, indeed, a revolutionary social science, a political science. As he admitted, "French thinkers... always think politically" [41, p. 33 ] and he is no exception to this rule. "Nothing is less innocent than non-interference" argued Bourdieu in his call for involved scientific action [39, p. 629]. Given the failures of the government, and the rising terror of globalization, it becomes the duty of social scientists - the last keepers of the tradition of the Enlightenment and its values - to remind the people of those values and to expose their betrayal by the governmental bodies, which were to implement them. As Grenfell suggested [1], Bourdieu was, indeed, a radical dissenter, an Agent Provocateur, whose work aimed to enlighten people and incite them to act [e.g. 33]. For Bourdieu, "the moment has come when scholars must intervene in politics, with all their competence, in order to establish utopias in truth and reason" [quoted in 1, p. 147].

The scientific part of Bourdieu's involved science had two main aims. The first objective was to expose deviations from equality and universality, or, in other words, to show that modern society is still class-based, with the majority of the population still being dominated by self-nominating elites. It was the duty of sociology, anthropology and the educational sciences to tear down the façade of liberal democracy and show it for what it has always been - an unjust order that preaches but never delivers on the promises of the Revolution [42]. It was hence the duty of sociologists to show that elite positions are socially distributed, thus negating the principles of justice and meritocracy. More fundamentally, it was their responsibility to criticize false aspirations for truth and objectivity, even within the world of science itself. The social world is not innocent, argued Bourdieu, and he felt responsible to keep the spirit of enlightened critique alive, and reproduce the "critical political tradition" of French sociology [43, p. 72]. The following excerpt attests to this position.

It is clearly necessary to get to the real economic and social determinants of the innumerable attacks on the freedom of individuals and their legitimate aspirations to happiness and self-fulfillment: determinants manipulated today not only by the merciless constraints of the 
labor and housing markets, but also by the decisions of the educational market and the overt penalties and covert aggressions of working life. To achieve this, it is necessary to break through the screen of often absurd, sometimes odious projections, that make the malaise or suffering as much as they express it [39, p. 629].

The moral bequeath of the social sciences, then, is to expose the betrayal of institutions and the deceptions engendered by discourses. Continuing the tradition of the philosophes, Bourdieu echoed their reasoning, suggesting that extant state institutions are human products; that they are socially constructed and arbitrary; and that they verge on dictatorship against the excluded - women, minorities, lower class students and peripheral countries. Similarly, he has shown that the symbolic violence against these groups is mostly attained by seemingly enlightened discourses that work to neutralize resistance by painting arbitrary social differentiations (and privileges) as natural - and hence merited and legitimate - differences.

Against this background, the second role of the social sciences is to explain - given the astounding gap between ideals and practice - why people uncritically accept this state of affairs. This concern was especially framed through the discussion of doxa and mis-recognition. His focus on the uncontested reproduction of the social order and the persistence of privileges sought new conceptual means to understand the current situation as a doxa, as a cognitively-unshakable though morally unjustified social order. By seeking out these mechanisms - cultural capital and habitus, for example - he adopted ideas from the Marxian tradition of exposing false consciousness borrowing from and expanding on ideas from Marx, Gramsci, and the members of the Frankfurt school.

However, his understanding of doxa and the conservative nature of the habitus more clearly followed the French intellectual tradition [16]. His explanation of the meshing of fields and habitus expanded on the important work of Durkheim and Mauss regarding the relation between social structure and thinking - originally published in Primitive Classification [44] and The Elementary Forms of Religious Life [45]. His emphasis on the congruity between mental structures and social structures - in other words on how normal natural thought seemed - has shown one mode of analysis, which can explain why the ancien régime is still here. His sophisticated discussion of the affinity between predispositions and social positions was incorporated with the concept of field to show who the combating camps are, and his emphasis on strategic action has facilitated an understanding of how systems or fields change through strategic maneuvers of the contestants. But he also explained why these changes do little in terms of transforming power positions. Bourdieu's entire theoretical apparatus reflects, then, his understanding of the Revolution and its inability to bring down the ancien régime.

So Bourdieu was motivated by the frustration of the Revolution; but was he hopeless in facing these recurring betrayals? No! Bourdieu remained a believer in the capacity of men and women to fight for a just republic.
This is why his version of social science sought out breaks and crises, and this is why he reflexively guarded his un-orthodox position, even within the discipline itself, which he viewed as another ancien régime, another battleground between revolutionary and reactionary forces.

Reflexive understanding is not enough, suggested Bourdieu. Cognizant of their commitment to the values of the French Revolution - and he envisions no alternative moral commitments for true intellectuals - he called on the social sciences to make a dent in the social order, to stab it where it is the least capable to resist, namely in its intellectual or symbolic armor. In discussing the role of intellectuals today, he was explicit about the need for political action, again following the Marxian dicta that it is time for philosophy to change the world, rather than merely interpret it. He thought that acts of scientific resistance are highly pertinent today because the counter-revolutionary forces - globalization, privatization of public services, the commercialization of art production and the literary world - are amassing more secretive weapons to curb the Revolution. His revolutionary stance thus called on scientists and artists to put brakes on the free reign of economic power over the now-endangered civil and human rights [46]. It was now time for academics to act. As he suggested elsewhere,

To reinforce autonomy by all means, is not necessarily to remain in the Ivory Tower among peers, among comrades. It is desirable, I think, that on the basis of this collectively guaranteed and collectively defended autonomy, artists, writers and scientists should sortie from their Tower with sword in hand, the symbolic sword in hand, the theoretical sword in hand, not at all in order to take political positions, but to affirm their own values and their own authority over important issues. For example, when a government takes measures that are racist, I think that it is important that, like Zola, the intellectuals, with the means at their disposal, should intervene so as to remind us of the values of universality, which constitute their profession... [47, pp. 4-5].

As this quote makes clear, social scientists are to be the new revolutionary agitators. Having the capacity to observe, record, and analyze the gap between the ideals of French Republicanism and their implementation, and having a moral commitment to the ideals of universality, justice, and meritocracy, the social sciences should be political sciences keeping light on those values while feeding men and women of action with ideas that will allow them to transform the suffering of the people into political action, which will cater for a just and morally justified social order. Bourdieu was not a utopian, though. He did not envision science to lead the revolution. Rather, he was "content with the partial and temporary truths that it can conquer against the common perception and intellectual doxa, truths able to secure the only rational means for using fully the margin of maneuver left to liberty, that is, to political action" [39, p. 629].

\section{VIVA LA REVOLUTION: CONCLUSIONS}

The present analysis has shown that Bourdieu was a man of the Revolution. He chose to stand by the ideals of egalitarianism and universalism - showing that the current 
social order is actually the ancien régime reincarnated in a new guise; that it is still arbitrary and unjust, exploitative and dominating. He was not the first to argue that many social institutions have managed to reproduce their functions whilst simply changing their names (e.g. Tocqueville). But he was, perhaps, the most vocal in criticizing the betrayal of the Revolutionary republican order. Specifically, he chose to expose its defectors - from the president of the republic to state administrative organs, from Parisian professors to the barons of art production. And he chose to expose how the people themselves obstruct - by embodying the habitus that reproduces their class position in society - the facile attempt to bring forth a just and egalitarian society. These choices are all of a family: They reflect a deeper choice by Bourdieu, namely to maintain vibrant the endangered chain of French Lumiers - philosophers like Jean-Jacques Rousseau and Condorcet, and authors like Emile Zola and Victor Hugo who gave words to suffering and enabled pragmatic social movements to drive toward a better world. Like Voltaire, Rousseau and Montesquieu before him, Bourdieu thought that he had prepared the critical intellectual tools that would work into and explicate the suffering and exclusion of citizens of the $21^{\text {st }}$ century. Frustrated by the gap between the ideals of the Republic and their materialization, Bourdieu was set on preparing the intellectual groundwork for another French Revolution.

This prism of "the frustration of the revolution" provides a new means of encompassing the seeminglyvaried studies conducted by Bourdieu. His study of masculine domination turns out to be much more than a polemic position in gender studies; and his studies of education are seen to lie outside the superficial debates over the causes of school failure. His agenda is that of the Enlightenment, his opponents are the counter revolutionaries. This is big sociology, or sociology with a big picture in mind: That of an historical era, which is yet to come. It should be noted, though, that the present interpretation of the Revolution as a deep code in Bourdieu's oeuvre cannot do justice to his immense body of writings. There are, indeed, many other important themes and concepts in his work, which the present paper leaves, untouched. Nevertheless, this deep cultural or political code - previously unacknowledged by other scholars - merits attention because it provides a clear unifying scheme to succinctly arrange and understand an otherwise overbearing body of work.

The present prism indeed provides an easy heuristic that ties together Bourdieu's theoretical apparatus and his worldview. One can understand - as Bourdieu emphasized time and again - that his concepts are all tied together; that field, habitus, cultural capital, embodiment and strategic action are all part of this big picture. Essentially, then, this prism helps to understand the overarching agenda, which unified Bourdieu's career. Prior investigations of one of these topics or previous studies of one of his concepts have thus missed the big picture, namely that Bourdieu's consistent and persistent oeuvre is driven by the frustration of the French Revolution.

Some commentators suggest that it would be advisable to read Bourdieu's writings against the background of his biography $[1,5,6]$. There is some merit to this approach. For example, one can reduce his critiques of schooling to his experience as a marginal country boy in an elite boarding school with bourgeoisie city-dwellers. One can better understand his emphases on repression and domination by appreciating his experience during the last days of colonial rule in Algiers. One can also interpret his angry critical analysis of the French university system by appreciating the tremendous cultural conversion he had to undergo in order to gain entrance to and succeed in the domain of the conservative Parisian intellectual elite. These personal experiences should, indeed, be taken into consideration when appreciating Bourdieu's theoretical and empirical corpus.

However, one should not over-stretch this biographical reduction. I subscribe to a milder position and argue that Bourdieu was able to understand his own existential suffering by using the French Revolution - its causes, aspirations and frustrations - as a cultural script. Similarly, he was able to understand the persistence of the ancien régime and its intricate mechanisms of reproduction because he personally felt the pressures pooled against him by seemingly supporting agencies of the state. The contrast between the ideals preached at him in school, and the actual betrayal of those values by the administration, were thus a personal indication of the larger ambivalent story the French society was writing for the past two centuries.

It is this story, which really mattered to Bourdieu. He succeeded in transforming his personal experiences of marginality to gain entrance to the French centers of power in order to continue writing this history. His duty was to continue the tradition of the French Enlightenment. He used his frustrations - the personal and the national - in order to help France take bolder steps toward achieving the promises inscribed by the people during and following the French Revolution. In that sense, Bourdieu was the champion of a just society and the keeper of the faith in the quest for perfection of humanity. In May 2003, when strikes again gripped France, "mass demonstrations converged on the Bastille, that symbolic center of the French revolutionary spirit. Among the many demonstrators holding placards, one perched on the corner of the Bastille monument declared 'remember Pierre Bourdieu'", [1, p. 192]. This is, indeed, how one needs to remember him: The last musketeer of the French Revolution.

\section{REFERENCES}

[1] Grenfell M. Pierre Bourdieu: Agent Provocateur. London: Continuum 2004.

[2] Durkheim E. On Morality and Society. In: Janowitz M, Ed. Chicago: The University of Chicago Press 1973.

[3] Censer JR, Hunt L. Liberty, Equality, Fraternity: Exploring the French Revolution. University Park, PA: Pennsylvania State University Press 2001.

[4] Swartz D. Culture \& Power: The Sociology of Pierre Bourdieu. Chicago: University of Chicago Press 1997.

[5] Jenkins R. Pierre Bourdieu. London: Routledge 1992.

[6] Robbins D. The Work of Pierre Bourdieu. Milton Keynes: Open University Press 1991.

[7] Lamont M, Lareau A. Cultural capital: Allusions, gaps and glissandos in recent theoretical developments. Soc Theory 1988; 6: 153-68.

[8] Moi T. Appropriating Bourdieu: Feminist theory and Pierre Bourdieu's sociology of culture. New Literary History 1991; 22: 1017-49.

[9] Bourdieu P. Viva la crise! For Heterodoxy in Social Science. Theor Soc 1988; 17(5): 773-87. 
[10] Stone B. Reinterpreting the French Revolution: A GlobalHistorical Perspective. Cambridge: Cambridge University Press 2002.

[11] Doyle W. Origins of the French Revolution. New York: Oxford University Press 1999.

[12] Behrens CBA. The Ancien Regime. London: Thames and Hudson 1967.

[13] Doyle W. Origins of the French Revolution. Oxford: Oxford University Press 1980.

[14] Bourdieu P. Homo Academicus. Stanford, CA: Stanford University Press 1988.

[15] Hugo V. The Complete Works of Victor Hugo: Ninety-Three London: Hawarden Press 1890.

[16] Levine DN. Visions of the Sociological Tradition. Chicago: University of Chicago Press 1995.

[17] Lemert C. Review: French Sociology: After the Patrons, What? Contemp Sociol 1986; 15(5): 689-92.

[18] Bourdieu P. The State Nobility: Elite Schools in the Field of Power. Stanford, Ca: Stanford University Press 1996.

[19] Bourdieu P, Passeron J. The Inheritors. Chicago: University of Chicago Press 1979.

[20] Bourdieu P, Passeron JC. Reproduction in Education, Society and Culture. London: Sage 1977.

[21] Bourdieu P, Darbel A. The Love of Art: European Art Museums and their Public. Stanford, Ca: Stanford University Press 1990.

[22] Bourdieu P. The forms of capital. In: Richardson JE, Ed. Handbook of Theory of Research for the Sociology of Education. New York: Greenwood Press 1986; pp. 241-58.

[23] Censer J, Hunt L. Imaging the French revolution: depictions of the French revolutionary crowd. Am Hist Rev 2005; 110(1): 3845

[24] Mirzoeff N. Revolution, representation, equality: Gender, genre, and emulation in the Academie Royale de Peinture et Sculpture 1785-93. Eight-Cen Stu 1998; 31(2):153-74.

[25] Godineau D. The Women of Paris and their French Revolution. Berkeley: University of California Press 1998.

[26] Roessler. Out of the Shadows: Women and Politics in the French Revolution, 1789-95. New York: Peter Lang 1998.

[27] Bourdieu P. Masculine Domination. Stanford, CA: Stanford University Press 2001

[28] Lovell T. Feminisms of the second wave. In: Turner BS, Ed. The Blackwell Companion to Social Theory. Oxford: Blackwell 2000; 299-324.
[29] Lovell T. Feminisms transformed? Post-structuralism and postmodernism. In: Turner BS, Ed. The Blackwell Companion to Social Theory. London: Blackwell 2000; 325-51.

[30] Bourdieu P. Practical Reason. Stanford, CA: Stanford University Press 1998.

[31] Bourdieu P. From the king's house to the reason of the state: A model of the genesis of the bureaucratic field. In: Wacquant L, Ed. Pierre Bourdieu and Democratic Politics: The Mystery of Ministry. Cambridge: Polity 2005; 29-54.

[32] Bourdieu P. On Television. New York: New Press 1998.

[33] Bourdieu P. Acts of Resistance: Against the Tyranny of the Market. New York: The New Press 1998.

[34] Bourdieu P. Firing Back: Against the Tyranny of the Market 2. New York: The New Press 2003.

[35] Bourdieu P. The Social Structure of the Economy. Cambridge, UK Polity 2005.

[36] Bourdieu P, Wacquant L. Neoliberal Newspeak: Notes on the New Planetary Vulgate. Rad Phil 2001; 105: 2-5.

[37] Weber M. The Protestant Ethic and the Spirit of Capitalism. New York: Charles Scribner's Sons 1958.

[38] Bourdieu P. The Rules of Art: Genesis and Structure of the Literary Field. Cambridge, UK: Polity Press 1996.

[39] Bourdieu P. The Weight of the World: Social Suffering in Contemporary Society. Stanford, Ca: Stanford University Press 1999.

[40] Heidegger M. Identity and Difference. New York: Harper \& Row 1969

[41] Bourdieu P. In Other Words: Essays Towards Reflexive Sociology. Stanford: Stanford University Press 1990.

[42] Bourdieu P. Sociology in Question. London; Thousand Oaks, Calif: Sage 1993.

[43] Bourdieu P, Wacquant LJD. An Invitation to Reflexive Sociology. Chicago: University of Chicago Press 1992.

[44] Durkheim E, Mauss M. Primitive Classification. Chicago: University of Chicago Press 1963.

[45] Durkheim E. The Elementary Forms of the Religious Life. New York: Collier 1961.

[46] Bourdieu P, Haacke H. Free Exchange. Cambridge: Polity 1995

[47] Bourdieu P. The role of intellectuals today. Theoria: J Soc Political Theo 2002; 99: 1-6.

(C) Gad Yar; Licensee Bentham Open.

This is an open access article licensed under the terms of the Creative Commons Attribution Non-Commercial License (http://creativecommons.org/licenses/by$\mathrm{nc} / 3.0 /$ ), which permits unrestricted, non-commercial use, distribution and reproduction in any medium, provided the work is properly cited. 